\title{
STUDY ON ELASTIC PROPERTY OF MIXED FIBER REINFORCED CONCRETE
}

\author{
Urooj Masood $^{1}$, B. L. P. Swami ${ }^{2}$, A. K. Asthana ${ }^{3}$ \\ ${ }^{1}$ Professor, Civil Engineering, Deccan College of Engineering and Technology, Darussalam, Hyderabad, 500001, TS, \\ India.uroojmasood@gmail.com \\ ${ }^{2}$ Professor, Coordinator, Research and Consultancy, Vasavi College of Engineering, Ibrahimbagh, Hyderabad, India. \\ ${ }^{3}$ Professor, Principal, Keshav Memorial College of Engineering and Technology, Narayanguda, Hyderabad, India.
}

\section{SYNOPSIS}

The present experimental investigation is conducted to study the elastic behavior of mixed fibers of AR HD glass and mild steel with an aspect ratio of 857 and 55. Microsilica in percentages of 5 and 15 also has been employed as a partial replacement to cement. Glass fiber and steel fiber were mixed by volume percentage in different proportions of 0 - 100, 25 -75, 50 - 50, 75 - 25 and $100-0$ in each of the total fiber percentages of $0.5,0.75,1.0$ and 1.5.

It is found from the test results that in a total fiber percent of 1.5 and with $15 \%$ microsilica, the MFRC specimens showed least strains and maximum values of direct modulus and initial secant modulus compared to specimens with $0 \%$ and $5 \%$ microsilica. Addition of glass fiber in certain percentage to steel fiber in the MFRC is resulting in substantial decrease in linear and lateral strains. From the fiber combinations, $100 \%$ steel fiber without glass fiber is giving the highest modulus. With other mixed combinations of glass and steel fibers like 75\% - 25\%, 50\% - 50\% and 25\% - 75\%, the failure of the specimens is found to be smoother with better crack behavior though modulus is lower compared to $100 \%$ steel fiber.

Keywords: Mixed Fiber. Fiber Percentage. Linear Strain. Lateral Strain. Elastic Modulus.

\section{INTRODUCTION}

The concrete-reinforcing fibers include metallic and non metallic like steel, polypropylene and various other types ${ }^{(1)}$. Fiber Reinforced concrete can be an economic and useful construction material $^{(2,3,17)}$. The knowledge of modulus of elasticity is required to avoid excessive deformations and to maintain stiffness of the material ${ }^{(8,9)}$. Pozzolonic admixture like Microsilica is used to enhance the packing of the mix because of its extreme finesse. Compression tests were conducted to measure strains by embedding strain gauge units in the normal weight and light weight concrete cylinders $^{(18)}$. Tests conducted on stress strain relationships for concrete also showed that the conditions such as the rate of loading, load repetitions, the magnitude of the repeated stresses influence the stress strain curve of concrete ${ }^{(16,19)}$. The aim of this research work is to study the stress strain behaviour and elastic modulus of Mixed Fiber Reinforced Concrete by introducing the mixed fibers of glass and steel in varying percentages in different total fiber mixes by volume along with microsilica.

\section{EXPERIMENTAL INVESTIGATIONS}

The following materials are used for the casting of specimens.

Cement

Ordinary Portland cement of 53 Grade from Ultra Tech conforming to I.S: $12269^{(15)}$ is used.

Fine Aggregate

River sand locally available is used as fine aggregate conforming to I.S: $383^{(10)}$
Coarse Aggregate

Machine crushed well graded angular granite aggregate of nominal size from local source is used conforming to I.S: $383^{(10)}$

Microsilica

Densified microsilica 920 D supplied by M/S Elkem India Pvt. Ltd. Mumbai was used. The typical bulk density is ranged between $500 \mathrm{Kg} / \mathrm{m}^{3}-700 \mathrm{Kg} / \mathrm{m}^{3}$ and specific surface of $3200 \mathrm{~m}^{2} /$ gram conforming to standard ASTM C $1240^{(6)}$.

Water Potable water locally available is used for mixing and curing the concrete.

Glass Fiber and Steel Fiber

Fibers of alkali resistant glass with an aspect ratio of 857:1 and steel fiber with an aspect ratio of 55 are used conforming to ASTM C $1666 \mathrm{M}^{(7)}$ and ASTM A $820 \mathrm{M}^{(4)}$. The details are given in table 1 .

Concrete Mix Details

The details of the M25 Concrete mix used are given in table 2 is arrived at as per I.S: $10262^{(11,14)}$.

Casting, Curing and Testing of Specimens

For determining the Elastic properties of MFRC, required number of standard cylinder specimens were cast, cured ${ }^{(13)}$ and tested ${ }^{(5,12)}$ following standard procedures. A Compressometer and an Extensometer are used to obtain the Elastic properties.

\section{DISCUSSION OF RESULTS}

The tabulated results of linear strain, lateral strain, modulus of elasticity and secant modulus of MFRC specimens with 
$0 \%, 5 \%$ and $15 \%$ microsilica are shown in tables 3 to 9 and in figures 1 to 3 .

1. Strain Effect on MFRC specimens without Microsilica with reference to base reference specimens (tables 3 and 4)

Base reference specimens (control) were found to have maximum linear and lateral strain when compared to MFRC specimens. These strains are found to be reducing with increasing total fiber percentages and have maximum reductions in total fiber percent of 1.5. In the mixed fiber proportions, the linear and lateral strains are found to be increasing with increase in percentage of glass fiber, but these strains are found to have more reductions when compared to base reference specimens. The control specimens have linear strain of $6.275 \times 10^{-3}$ and lateral strain of $22.267 \times 10^{-3}$ at ultimate load. In total fiber percent of 1.5 with $100 \%$ steel fiber proportion, the linear and lateral strains are found to have a reduction of $80.87 \%$ and $85.92 \%$ when compared with the base reference specimens. In the same total fiber percent of 1.5 with $25 \%$ glass fiber and $75 \%$ steel fiber proportion and with $100 \%$ glass fiber proportion, the linear and lateral strains are found to have reductions of $74.90 \%, 78.59 \%$ and $49 \%, 64.07 \%$ respectively over the base reference specimens.

2. Strain Effect on MFRC specimens with Microsilica and with reference to reference specimens (tables 3 and 4)

Addition of microsilica to plain concrete specimens as partial replacement of cement by weight now referred as reference specimens has reduced the strains in the concrete specimens. With 5 percent microsilica in concrete, the linear and lateral strains are found to be $5.925 \times 10^{-3}$ and $19.800 \mathrm{x}$ $10^{-3}$ respectively. With 15 percent microsilica in concrete, the linear and lateral strains are found to be $4.075 \times 10^{-3}$ and $16.43 \times 10^{-3}$ respectively. Reference specimens with microsilica are found to have reduced linear and lateral strains when compared to base reference specimens. The specimens with $5 \%$ microsilica in concrete called reference specimens are found to have reductions of $5.58 \%$ and $11.08 \%$ in linear strain and lateral strain and with $15 \%$ microsilica in concrete, the respective strains are found to reduce by $35.06 \%$ and $26.21 \%$ over the base reference specimens. The linear and lateral strains in MFRC specimens are found to be reducing with increasing total fiber percentages and microsilica percentages. MFRC specimens with $15 \%$ microsilica and $1.5 \%$ total fiber are found to have maximum reductions in the values of linear and lateral strain. In the mixed fiber proportions, the linear and lateral strains are found to be increasing with increase in percentage of glass fiber, but these strains are found to have more reductions when compared to reference specimens. In a total fiber percent of 1.5 with $5 \%$ microsilica and $100 \%$ steel fiber at ultimate load, the reductions in linear and lateral strains are found to be $82.70 \%$ and $86.03 \%$. With $25 \%$ glass fiber and $75 \%$ steel fiber proportion, the strains are reduced by $75.52 \%$ and $81.4 \%$. With $100 \%$ glass fiber, the strains are reduced by $61.60 \%$ and $68.02 \%$ when compared with the respective reference specimens. In the same total fiber percent of 1.5 with $15 \%$ microsilica and $100 \%$ steel fiber, the linear and lateral strain reductions are found to be $85.28 \%$ and $87.82 \%$ over their respective reference specimens. With $25 \%$ glass fiber and $75 \%$ steel fiber proportion, the linear and lateral strains are found to reduce by $80.98 \%$ and $85.19 \%$. With $100 \%$ glass fiber the linear and lateral strains are reduced by $62.57 \%$ and $75.04 \%$ in the same total fiber percent of 1.5 with $15 \%$ microsilica. The MFRC specimens with $15 \%$ microsilica addition as partial replacement to cement are found to have highest reductions in linear and lateral strains when compared to MFRC specimens with 5\% microsilica and MFRC specimens without microsilica. Increase in microsilica percentage from 5 to 15 in concrete has enhanced the reductions in strains in the MFRC specimens.

3. Strain Effect on MFRC Specimens with and without Microsilica over the base reference specimens (table 5)

The linear and lateral strain reductions of $83.67 \%$ and $87.57 \%$ in a total fiber percent of 1.5 with $100 \%$ steel fiber are found over the base reference specimens showing a reduction of $2.8 \%$ and $1.65 \%$ in linear and lateral strains over the MFRC specimens without microsilica. In the same total fiber percent of 1.5 and with 15 percent microsilica, the specimens with 100 percent steel fiber showed reductions of 90.44 percent and 91.02 percent in the linear and lateral strains over the base reference specimens, showing a reduction of 9.57 percent and 5.1 percent in linear and lateral strains when compared to MFRC specimens without microsilica in the same proportion. The MFRC specimens with mixed fibers of 25 percent glass fiber and 75 percent steel fiber in a total fiber percent of 1.5 with 5 percent microsilica showed reductions of 76.89 percent and 82.23 percent in linear and lateral strains when compared to the base reference specimens. These MFRC specimens showed reductions of 1.99 percent and 4.64 percent in linear and lateral strain over the MFRC specimens without microsilica in the same proportion. In the same total fiber percent of 1.5 and 15 percent microsilica the specimens with 25 percent glass fiber and 75 percent steel fiber showed reductions of 87.65 percent and 89.07 percent in linear and lateral strains when compared to the base reference specimens. These MFRC specimens showed reductions of 12.75 percent and 10.48 percent in linear and lateral strains over the MFRC specimens without microsilica in the same proportion. Similarly the MFRC specimens with 100 percent glass fiber in a total fiber percent of 1.5 and with 5 percent microsilica showed reductions of 63.74 percent and 71.55 percent in linear and lateral strains when compared to the base reference specimens. These MFRC specimens showed reductions of 14.74 percent and 7.48 percent in linear and lateral strains over the MFRC specimens without microsilica in the same proportion. In the same total fiber percent of 1.5 with 100 percent glass fiber and 15 percent microsilica, the MFRC specimens showed reductions of 75.69 percent and 81.59 percent in linear and lateral strains when compared to the base reference specimens. These MFRC specimens showed reductions of 26.69 percent and 17.52 percent in linear and lateral strains over the MFRC specimens of the same proportions without microsilica. This showed, that the mixed fibers and microsilica have provided higher reductions in strains when compared to specimens without fibers and without microsilica. 
4. Modulus of Elasticity of MFRC without Microsilica (tables 6, 9 and figure 1)

In the procedure given by the ASTM C 469 code, 40 percent of the ultimate load is considered for the computation of secant modulus. All the values of Young's modulus were computed upto this point and average is taken. As per I.S. Code procedure Modulus of Elasticity is calculated by taking direct stress to direct strain upto 40 percent of ultimate load which represents the linear portion almost. The modulus of elasticity upto 40 percent of the ultimate load and secant modulus of elasticity $\left(\mathrm{E}_{\mathrm{sc}}\right)$ at $40 \%$ of ultimate load in the specimens with fibers are found to be higher when compared to the reference specimens (control) without fibers. These same are found to be $12941 \mathrm{~N} / \mathrm{mm}^{2}$ and 12768 $\mathrm{N} / \mathrm{mm}^{2}$. It is observed at $40 \%$ of ultimate load the secant modulus is getting reduced when compared to the modulus of elasticity. In the various percentages of mixed fibers in different total fiber percentages, the specimens with 100 percent steel fibers are found to have maximum increase in modulus of elasticity when compared to specimens with other mix percentages. The modulus of elasticity and secant modulus are found to be decreasing with increase in percentage of glass fiber, but these elasticity's are more when compared with control specimens. The maximum increases in the values of elasticity are observed in the specimens with total fiber percent of 1.5. The modulus of elasticity and secant modulus in the specimens with 100 percent steel fiber in a total fiber percent of 1.5 are found to be $74307 \mathrm{~N} / \mathrm{mm}^{2}$ and $61542 \mathrm{~N} / \mathrm{mm}^{2}$. There is an increase in modulus of elasticity by more than 4.5 times, when compared to the reference specimens (control). With 100 percent glass fiber in a total fiber percent of 1.5 the modulus of elasticity and secant modulus in the specimens are found to be $28380 \mathrm{~N} / \mathrm{mm}^{2}$ and $27571 \mathrm{~N} / \mathrm{mm}^{2}$. There is an increase in modulus of elasticity by 119.30 percent when compared to the reference specimens. With 25 percent glass fiber and 75 percent steel fiber in the specimens with a total fiber percent of 1.5 the modulus of elasticity and secant modulus in the specimens are found to be $55685 \mathrm{~N} / \mathrm{mm}^{2}$ and 53045 $\mathrm{N} / \mathrm{mm}^{2}$. There is an increase in modulus of elasticity by more than 3.3 times the modulus of elasticity of the reference specimens.

5. Modulus of Elasticity of MFRC with Microsilica (tables 7, 8, 9 and figure 2)

The addition of microsilica as partial replacement to cement in the concrete has increased the modulus of elasticity and secant modulus. With 5 percent microsilica in the concrete, the modulus of elasticity and secant modulus are 13655 $\mathrm{N} / \mathrm{mm}^{2}$ and $13516 \mathrm{~N} / \mathrm{mm}^{2}$ respectively. With 15 percent microsilica in concrete, the modulus of elasticity and secant modulus are found to be $17258 \mathrm{~N} / \mathrm{mm}^{2}$ and $15813 \mathrm{~N} / \mathrm{mm}^{2}$ respectively. Increase in microsilica percentage from 5 to 15 in the concrete has showed maximum increase in the modulus of elasticity and secant modulus in the MFRC specimens. Higher values of modulus of elasticity and secant modulus are found in specimens with various percentages of mixed fibers in a total fiber percent of 1.5 with 5 percent microsilica, when compared to the respective reference specimens with 5 percent microsilica and no fibers. In the same percentage of 1.5 total fibers and with 100 percent steel fiber and 5 percent microsilica in the specimens, the modulus of elasticity and secant modulus at 40 percent of ultimate load are found to be $93480 \mathrm{~N} / \mathrm{mm}^{2}$ and $87960 \mathrm{~N} / \mathrm{mm}^{2}$. There is an increase in modulus of elasticity by more than 5.8 times when compared with the respective reference specimens. With 5 percent microsilica and 100 percent glass fiber in the same total fiber percent of 1.5 upto 40 percent ultimate load and at $40 \%$ of ultimate load, the modulus of elasticity and secant modulus are found to be $41502 \mathrm{~N} / \mathrm{mm}^{2}$ and $41410 \mathrm{~N} / \mathrm{mm}^{2}$ respectively. There is an increase of 203.93 percent in modulus of elasticity when compared to the respective reference specimens. In the same total fiber percent of 1.5 , the mixed fibers of 25 percent glass fiber and 75 percent steel fiber in the concrete with 5 percent microsilica are found to have the modulus of elasticity and secant modulus as $78727 \mathrm{~N} / \mathrm{mm}^{2}$ and 72133 $\mathrm{N} / \mathrm{mm}^{2}$ respectively. There is an increase in modulus of elasticity by more than 4.7 times when compared with the reference specimens. In the same total fiber percent of 1.5 with 5 percent microsilica and with increase in glass fiber content in the mixed percentages of fibers in all the specimens, the modulus of elasticity is found to be reducing and the same is true in all the other specimens with different total fiber percentages. The MFRC specimens with 15 percent microsilica and 100 percent steel fiber in a total fiber percent of 1.5 upto 40 percent of ultimate load has a modulus of elasticity of $121957 \mathrm{~N} / \mathrm{mm}^{2}$ and at $40 \%$ of ultimate load the secant modulus is found to be 114600 $\mathrm{N} / \mathrm{mm}^{2}$. There is an increase by more than 6 times in modulus of elasticity when compared to the respective reference specimens with 15 percent microsilica. Within this same total fiber percent of 1.5 and 100 percent glass fiber with 15 percent microsilica upto the load of 40 percent of ultimate load and at $40 \%$ of ultimate load, the modulus of elasticity and secant modulus are found to be $66809 \mathrm{~N} / \mathrm{mm}^{2}$ and $55147 \mathrm{~N} / \mathrm{mm}^{2}$ respectively. There is an increase in modulus of elasticity of this MFRC by more than 2.8 times the modulus of elasticity of the respective reference specimens with 15 percent microsilica. In the same total fiber percent of 1.5 with mixed fibers of 25 percent glass and 75 percent steel and 15 percent microsilica, the modulus of elasticity and secant modulus are found to be 101451 $\mathrm{N} / \mathrm{mm}^{2}$ and $89760 \mathrm{~N} / \mathrm{mm}^{2}$ respectively. There is an increase in modulus of elasticity by more than 4.8 times the modulus of elasticity of the respective reference specimens. In the same total fiber percent of 1.5 with increasing percentage of glass fiber in various mixed fibers percentages and with 15 percent microsilica, there is a decreasing trend in modulus of elasticity and secant modulus. The same trend is true in other MFRC specimens with different total fiber percentages. Thus it is seen with 15 percent microsilica that the modulus of elasticity and secant modulus values obtained are much higher when compared to the MFRC specimens with 5 percent microsilica.

6. Modulus of Elasticity of MFRC with and without Microsilica (table 9 and figure 3)

The reference specimens with 5 percent and 15 percent microsilica as partial replacement of cement and with no 
fibers are observed to have increased modulus of elasticity by 5.52 percent and 33.36 percent respectively. The same reference specimens are found to have an increased secant modulus by 5.86 percent and 23.84 percent when compared with the base reference specimens without microsilica and without fibers. The MFRC specimens with 5 percent microsilica and total fiber percent of 1.5 with various mixed fiber percentages have shown increased modulus of elasticity and secant modulus. In this, with 100 percent steel fiber an increase by more than 6 times the modulus of elasticity and more than 5.8 times the secant modulus of the base reference specimens are observed. The MFRC specimens with a total fiber percent of 1.5 and 100 percent steel fiber with 15 percent microsilica have shown an increase by more than 8.4 times and more than 7.9 times the modulus of elasticity and secant modulus of the base reference specimens. In this same total fiber percent of 1.5 there is an increase by 195.29 percent and 144.74 percent in the Modulus of elasticity and secant modulus of the MFRC specimens with 5 percent microsilica over the base reference specimens. There is an increase in the MFRC specimens with 15 percent microsilica by 405.24 percent and 297.09 percent in the Modulus of elasticity and secant modulus when compared to the base reference specimens. Similarly the MFRC specimens with 100 percent glass fiber in a total fiber percent of 1.5 and with 5 and 15 percent microsilica showed an increase in modulus of elasticity by more than 2.2 times and more than 4 times when compared to the base reference specimens. There is an increase of 220.70 percent and 416.26 percent over the base reference specimens. The same is true for secant modulus showing an increase by more than 2 times and 3 times when compared to the base reference specimens. There is an increase of 224.33 percent and 331.92 percent over the base reference. The MFRC specimens with mixed fibers of 25 percent glass fiber and 75 percent steel fiber in a total fiber percent of 1.5 and with 5 and 15 percent microsilica have shown an increase in modulus of elasticity by more than 5 times and 6.8 times over the base reference specimens. There is an increase of 508.33 percent and 683.95 percent over the base reference specimens in the modulus of elasticity values. In the same total fiber percent of 1.5 and mixed fibers percentages of 25 percent glass and 75 percent steel with 5 percent and 15 percent microsilica, the increases in secant modulus are by more than 4.5 and 5 times the initial secant modulus of the base reference specimens. There is an increase of 464.95 percent and 603.01 percent respectively over the base reference specimens. It is observed that the MFRC with 15 percent microsilica have provided maximum increase in modulus of elasticity and secant modulus when compared to MFRC specimens without fiber and MFRC specimens with 5 percent microsilica.

\section{CONCLUSIONS}

[1]. Mixed fiber combination results in substantial decrease in the linear and lateral strains. Optimum percentage of microsilica used as replacement to cement contributes to further decrease.

[2]. The reference specimens with $15 \%$ microsilica have shown more elastic nature compared to specimens with zero percent and $5 \%$ microsilica.

[3]. Strains in the MFRC specimens are decreasing with increase in total fiber percentages from $0.0 .5,0.75,1.0$ and 1.5. Specimens with $100 \%$ steel fibers in a total fiber percent have shown higher reductions in strains when compared to specimens with mixed fibers of glass and steel. The specimens with $100 \%$ glass fiber have exhibited higher strains. The specimens with total fiber percent of 1.5 have exhibited least strains. Optimum $15 \%$ of microsilica used as replacement to cement contributes to further decrease but showing a stiff failure at ultimate load.

[4]. The MFRC specimens with all individual percentages have shown maximum values of modulus of elasticity and secant modulus in a total fiber percent of 1.5. The specimens with $100 \%$ steel fibers have shown the maximum elastic modulus.

\section{ACKNOWLEDGEMENTS}

The authors wish to place on record the help provided by the managements and the academic teaching and non teaching faculties of Vasavi college of Engineering, Ibrahimbagh, and Deccan college of Engineering and Technology Darussalam, Hyderabad in the completion of this project.

\section{REFERENCES}

[1]. ACI 544.1 R-96, (Reapproved 2009) 'Report on fiber reinforced concrete'.

[2]. ACI 544.2 R-89, (Reapproved 2009) 'Measurement of properties of fiber reinforced concrete'.

[3]. ACI 544.3 R-08, 'Guide for specifying proportioning and production of fiber reinforced concrete'.

[4]. ASTM A 820M-06, 'Specification for Steel Fibers for Fiber Reinforced Concrete'. ASTM International.

[5]. ASTM C 469M-10, 'Standard test method for state module of elasticity and poisson ratio of concrete in compression'. ASTM International.

[6]. ASTM C 1240-05, 'Standard Specification for Silica Fume used in Cementitous Mixtures'. ASTM International.

[7]. ASTM C 1666M-08, 'Standard Specification for Alkali Resistant (AR) Glass Fiber for GFRC and Fiber Reinforced Concrete and Cement'. ASTM International.

[8]. Byung Wan Jo, Young Hyun Shen, Young Jim Kim, 'The Evaluation of Elastic Modulus for Steel Fiber Reinforced Concrete'. Russian Journal of Non Destructive Testing, vol.37, No. 2, 2001, PP. 152161.

[9]. Francesco Bencardino, Lidia Rizzuti, Giuseppe Spadea and Ramnath N. Swamy, 'Stress Strain behaviour of Steel Fiber Reinforced Concrete in Compression'. Journal of materials in Civil Engineering, vol.20, No. 3, 2008, PP255-263.

[10]. I.S. 383-1970, 'Specification for course and fine aggregate from natural sources for concrete'. BIS.

[11]. I.S. 456-2000, 'Code of practice of plain and reinforced concrete'. BIS.

[12]. I.S. 516-1959, 'Method of test for strength of 
concrete', BIS.

[13]. I.S. 6461 (Part 7) 1973 'Mixing, laying, compaction, curing and other construction aspects', BIS.

[14]. I.S. 10262-2009, 'Recommended guidelines for concrete mix design'. BIS.

[15]. I.S. 12269-1987, 'Specification for 53 grade ordinary Portland cement'. BIS.

[16]. K.K. Sideris, P. Manita, K. Sideris, 'Estimation of ultimate modulus of Elasticity and Poisson ratio of normal concrete'. Cement and Concrete Composites, 26, 2004, PP. 623-631.

[17]. Majumdar, A. J. 'Fiber reinforced cement and concrete composite' RILEM Symposium 1975. PP.279-313.

[18]. Sami A. Klink, 'Actual Elastic Modulus of Concrete'. ACI Journal, Sep. -Oct. 1985, PP. 630633.

[19]. Sandor Popovics, 'A Review of Stress Strain relationship for concrete'. ACI Journal, March 1970, PP. 243-248.
Table 1. Properties of Fibers (Glass and Steel)

\begin{tabular}{|c|c|c|c|c|c|c|c|}
\hline $\begin{array}{l}\text { Fib } \\
\text { er }\end{array}$ & $\begin{array}{l}\text { Ty } \\
\text { pe }\end{array}$ & $\begin{array}{l}\text { Dens } \\
\text { ity } \\
\mathrm{kg} / \mathrm{m}\end{array}$ & $\begin{array}{l}\text { Elasti } \\
\text { c } \\
\text { modu } \\
\text { lus } \\
\text { GPA }\end{array}$ & $\begin{array}{l}\text { Tens } \\
\text { ile } \\
\text { stren } \\
\text { gth } \\
\text { MP } \\
\text { A }\end{array}$ & Dia. & $\begin{array}{l}\text { Len } \\
\text { gth } \\
\text { mm }\end{array}$ & $\begin{array}{l}\text { No. } \\
\text { of } \\
\text { fiber }\end{array}$ \\
\hline $\begin{array}{l}\text { AR } \\
- \\
\text { Gla } \\
\text { ss }\end{array}$ & $\begin{array}{l}\mathrm{Ce} \\
\mathrm{m}- \\
\mathrm{FI} \\
\mathrm{L} \\
\mathrm{AR} \\
\mathrm{C} \\
14 \\
30 \\
6 \\
\mathrm{HD}\end{array}$ & 2600 & 73 & 1700 & $\begin{array}{l}14 \\
\text { micr } \\
\text { on }\end{array}$ & 12 & $\begin{array}{l}212 \\
\text { milli } \\
\text { on } \\
/ \mathrm{kg}\end{array}$ \\
\hline $\begin{array}{l}\text { Ste } \\
\text { el }\end{array}$ & $\begin{array}{l}\text { Ste } \\
\text { el } \\
\text { wir } \\
\text { e }\end{array}$ & 7850 & 210 & 250 & $\begin{array}{l}1 \mathrm{~m} \\
\mathrm{~m}\end{array}$ & 55 & $\begin{array}{l}\text { Mon } \\
\text { o } \\
\text { filam } \\
\text { ent }\end{array}$ \\
\hline
\end{tabular}

Table 2. Materials Required for 1 Cubic Meter of Concrete

\begin{tabular}{|l|l|l|l|l|}
\hline Grade & $\begin{array}{l}\text { Cement } \\
(\mathrm{kg})\end{array}$ & $\begin{array}{l}\text { Fine } \\
\text { aggregate } \\
(\mathrm{kg})\end{array}$ & $\begin{array}{l}\text { Coarse } \\
\text { aggregate } \\
(\mathrm{kg})\end{array}$ & $\begin{array}{l}\text { Water } \\
\text { cement } \\
\text { ratio }\end{array}$ \\
\hline $\mathrm{M} 25$ & 400 & 640 & 1200 & 0.5 \\
\hline
\end{tabular}

Table 3. Linear and Lateral Strain Values of MFRC Specimens in Compression at Ultimate Load with Various Percentages of Microsilica

\begin{tabular}{|c|c|c|c|c|c|c|c|c|}
\hline \multirow{2}{*}{$\begin{array}{l}\text { Total } \\
\text { Fiber } \\
(\%)\end{array}$} & \multicolumn{2}{|c|}{ Mixed Fiber (\%) } & \multicolumn{3}{|c|}{$\begin{array}{l}\text { Linear Strain at Ultimate Load with } \\
\text { Microsilica } \times 10^{-3}\end{array}$} & \multicolumn{3}{|c|}{$\begin{array}{l}\text { Lateral Strain at Ultimate Load with } \\
\text { Microsilica } \times 10^{-3}\end{array}$} \\
\hline & Glass & Steel & $0 \%$ & $5 \%$ & $15 \%$ & $0 \%$ & $5 \%$ & $15 \%$ \\
\hline 0.0 & 0.0 & 0.0 & 6.275 & 5.925 & 4.075 & 22.267 & 19.800 & 16.43 \\
\hline 0.50 & 0 & 100 & 5.200 & 2.675 & 2.000 & 10.660 & 7.000 & 6.33 \\
\hline 0.50 & 25 & 75 & 5.300 & 2.975 & 2.375 & 11.100 & 7.533 & 7.100 \\
\hline 0.50 & 50 & 50 & 5.950 & 3.150 & 2.525 & 11.400 & 8.600 & 8.166 \\
\hline 0.50 & 75 & 25 & 6.025 & 3.300 & 2.800 & 12.500 & 11.000 & 9.350 \\
\hline 0.50 & 100 & 0 & 6.175 & 3.525 & 3.075 & 12.900 & 11.433 & 10.43 \\
\hline 0.75 & 0 & 100 & 4.075 & 2.075 & 1.700 & 9.100 & 6.700 & 6.10 \\
\hline 0.75 & 25 & 75 & 4.525 & 2.350 & 1.975 & 9.900 & 7.100 & 6.400 \\
\hline 0.75 & 50 & 50 & 5.100 & 2.575 & 2.250 & 10.800 & 7.900 & 7.200 \\
\hline 0.75 & 75 & 25 & 5.675 & 2.975 & 2.450 & 11.400 & 8.700 & 7.966 \\
\hline
\end{tabular}




\begin{tabular}{|l|l|l|l|l|l|l|l|l|}
\hline 0.75 & 100 & 0 & 5.875 & 3.175 & 2.700 & 12.000 & 10.100 & 9.30 \\
\hline 1.00 & 0 & 100 & 1.825 & 1.600 & 0.750 & 5.633 & 4.567 & 2.533 \\
\hline 1.00 & 25 & 75 & 2.250 & 1.625 & 0.850 & 6.233 & 5.133 & 3.167 \\
\hline 1.00 & 50 & 50 & 2.600 & 2.225 & 1.000 & 6.933 & 6.300 & 3.767 \\
\hline 1.00 & 75 & 25 & 3.300 & 2.375 & 1.150 & 8.760 & 7.100 & 4.867 \\
\hline 1.00 & 100 & 0 & 3.850 & 2.700 & 1.750 & 9.367 & 8.300 & 5.167 \\
\hline 1.50 & 0 & 100 & 1.200 & 1.025 & 0.600 & 3.133 & 2.766 & 2.000 \\
\hline 1.50 & 25 & 75 & 1.575 & 1.450 & 0.775 & 4.767 & 3.733 & 2.433 \\
\hline 1.50 & 50 & 50 & 2.025 & 1.750 & 0.950 & 6.133 & 4.833 & 2.967 \\
\hline 1.50 & 75 & 25 & 2.450 & 2.100 & 1.150 & 6.677 & 5.633 & 3.400 \\
\hline 1.50 & 100 & 0 & 3.200 & 2.275 & 1.525 & 8.000 & 6.333 & 4.100 \\
\hline
\end{tabular}

Table 4. Linear and Lateral Strain Values of MFRC Specimens in Compression at Ultimate Load with Various Percentages of Microsilica over the Respective Reference

\begin{tabular}{|l|l|l|l|l|l|l|l|l|}
\hline \multirow{2}{*}{$\begin{array}{l}\text { Total } \\
\text { Fiber } \\
(\%)\end{array}$} & \multicolumn{2}{|l|}{ Mixed Fiber $(\%)$} & \multicolumn{3}{l|}{$\begin{array}{l}\text { Percent Reduction in Linear Strain with } \\
\text { microsilica } \text { Over the Respective Reference }\end{array}$} & \multicolumn{2}{l}{$\begin{array}{l}\text { Percent Reduction in Lateral Strain with } \\
\text { microsilica Over the Respective Refence }\end{array}$} \\
\cline { 2 - 9 } & Glass & Steel & $0 \%$ & $5 \%$ & $15 \%$ & $0 \%$ & $5 \%$ & $15 \%$ \\
\hline 0.0 & 0.0 & 0.0 & -- & -- & -- & -- & -- & -- \\
\hline 0.50 & 0 & 100 & 17.13 & 54.85 & 50.92 & 52.12 & 64.65 & 61.47 \\
\hline 0.50 & 25 & 75 & 15.54 & 49.79 & 41.72 & 50.15 & 61.95 & 56.78 \\
\hline 0.50 & 50 & 50 & 5.17 & 46.84 & 38.04 & 48.80 & 56.57 & 50.29 \\
\hline 0.50 & 75 & 25 & 3.98 & 44.30 & 31.29 & 43.86 & 44.44 & 43.09 \\
\hline 0.50 & 100 & 0 & 1.59 & 40.51 & 24.53 & 42.07 & 42.25 & 36.52 \\
\hline 0.75 & 0 & 100 & 35.06 & 64.98 & 58.28 & 59.13 & 66.16 & 62.87 \\
\hline 0.75 & 25 & 75 & 27.89 & 60.34 & 51.53 & 55.53 & 64.14 & 61.05 \\
\hline 0.75 & 50 & 50 & 18.73 & 56.54 & 44.78 & 51.49 & 61.67 & 56.18 \\
\hline 0.75 & 75 & 25 & 9.56 & 49.78 & 39.87 & 48.80 & 56.06 & 51.92 \\
\hline 0.75 & 100 & 0 & 6.37 & 46.41 & 33.74 & 46.11 & 48.98 & 43.39 \\
\hline 1.00 & 0 & 100 & 70.92 & 72.99 & 81.59 & 74.70 & 76.93 & 84.58 \\
\hline 1.00 & 25 & 75 & 64.14 & 72.56 & 79.14 & 72.01 & 74.08 & 80.72 \\
\hline 1.00 & 50 & 50 & 58.56 & 62.45 & 74.46 & 68.86 & 68.18 & 77.07 \\
\hline 1.00 & 75 & 25 & 47.41 & 59.92 & 71.78 & 60.65 & 64.14 & 70.37 \\
\hline
\end{tabular}




\begin{tabular}{|l|l|l|l|l|l|l|l|l|}
\hline 1.00 & 100 & 0 & 38.64 & 54.43 & 57.05 & 57.93 & 58.08 & 65.05 \\
\hline 1.50 & 0 & 100 & 80.87 & 82.70 & 85.28 & 85.92 & 86.03 & 87.82 \\
\hline 1.50 & 25 & 75 & 74.90 & 75.52 & 80.98 & 78.59 & 81.14 & 85.19 \\
\hline 1.50 & 50 & 50 & 67.72 & 70.46 & 76.69 & 72.46 & 75.59 & 81.94 \\
\hline 1.50 & 75 & 25 & 60.96 & 64.55 & 71.77 & 70.01 & 71.55 & 79.31 \\
\hline 1.50 & 100 & 0 & 49.00 & 61.60 & 62.57 & 64.07 & 68.02 & 75.04 \\
\hline
\end{tabular}

Respective Reference: Specimens with no fiber and respective $0 \%, 5 \%$ and $15 \%$ microsilica

Table 5. Linear and Lateral Strain Values of MFRC Specimens in Compression at Ultimate Load with Various Percentages of Microsilica over the Base Reference

\begin{tabular}{|c|c|c|c|c|c|c|c|c|}
\hline \multirow{2}{*}{$\begin{array}{l}\text { Total } \\
\text { Fiber } \\
(\%)\end{array}$} & \multicolumn{2}{|c|}{ Mixed Fiber (\%) } & \multicolumn{3}{|c|}{$\begin{array}{l}\text { Percent Reduction in Linear Strain with } \\
\text { microsilica Over the Base Reference }\end{array}$} & \multicolumn{3}{|c|}{$\begin{array}{l}\text { Percent Reduction in Lateral Strain with } \\
\text { microsilica Over the Base Reference }\end{array}$} \\
\hline & Glass & Steel & $0 \%$ & $5 \%$ & $15 \%$ & $0 \%$ & $5 \%$ & $15 \%$ \\
\hline 0.0 & 0.0 & 0.0 & -- & 5.58 & 35.06 & -- & 11.08 & 26.21 \\
\hline 0.50 & 0 & 100 & 17.13 & 57.37 & 68.12 & 52.12 & 68.56 & 71.57 \\
\hline 0.50 & 25 & 75 & 15.54 & 52.58 & 62.15 & 50.15 & 66.17 & 68.11 \\
\hline 0.50 & 50 & 50 & 5.17 & 49.80 & 59.76 & 48.80 & 61.38 & 63.33 \\
\hline 0.50 & 75 & 25 & 3.98 & 47.41 & 55.37 & 43.86 & 50.59 & 58.01 \\
\hline 0.50 & 100 & 0 & 1.59 & 43.82 & 50.99 & 42.07 & 48.65 & 53.16 \\
\hline 0.75 & 0 & 100 & 35.06 & 66.93 & 72.91 & 59.13 & 69.91 & 72.60 \\
\hline 0.75 & 25 & 75 & 27.89 & 62.54 & 68.52 & 55.53 & 68.11 & 71.25 \\
\hline 0.75 & 50 & 50 & 18.73 & 58.96 & 64.14 & 51.49 & 64.52 & 67.67 \\
\hline 0.75 & 75 & 25 & 9.56 & 52.58 & 60.96 & 48.80 & 60.93 & 64.22 \\
\hline 0.75 & 100 & 0 & 6.37 & 49.40 & 56.97 & 46.11 & 54.64 & 58.23 \\
\hline 1.00 & 0 & 100 & 70.92 & 74.50 & 88.05 & 74.70 & 79.48 & 88.62 \\
\hline 1.00 & 25 & 75 & 64.14 & 74.10 & 86.45 & 72.01 & 76.94 & 85.78 \\
\hline 1.00 & 50 & 50 & 58.56 & 64.54 & 84.06 & 68.86 & 71.70 & 83.08 \\
\hline 1.00 & 75 & 25 & 47.41 & 62.15 & 81.67 & 60.65 & 68.11 & 78.14 \\
\hline 1.00 & 100 & 0 & 38.64 & 56.97 & 72.11 & 57.93 & 62.73 & 76.79 \\
\hline 1.50 & 0 & 100 & 80.87 & 83.67 & 90.44 & 85.92 & 87.57 & 91.02 \\
\hline 1.50 & 25 & 75 & 74.90 & 76.89 & 87.65 & 78.59 & 83.23 & 89.07 \\
\hline 1.50 & 50 & 50 & 67.72 & 72.11 & 84.86 & 72.46 & 78.29 & 86.68 \\
\hline 1.50 & 75 & 25 & 60.96 & 66.53 & 81.67 & 70.01 & 74.70 & 84.73 \\
\hline 1.50 & 100 & 0 & 49.00 & 63.74 & 75.69 & 64.07 & 71.55 & 81.59 \\
\hline
\end{tabular}

Base Reference: Specimens with no fiber and no microsilica 
Table 6. Modulus of Elasticity and Secant Modulus of MFRC Specimens With $0 \%$ Microsilica

\begin{tabular}{|c|c|c|c|c|c|c|}
\hline \multirow{2}{*}{$\begin{array}{l}\text { S. } \\
\text { No. }\end{array}$} & \multirow{2}{*}{$\begin{array}{l}\text { Total } \\
\text { Fiber }(\%)\end{array}$} & \multicolumn{2}{|c|}{ Mixed Fiber (\%) } & \multirow{2}{*}{$\begin{array}{l}\text { Modulus of Elasticity } \\
\left(\mathrm{E}_{\mathrm{C}}\right)\left(\mathrm{N} / \mathrm{mm}^{2}\right) \\
\text { (Average) }\end{array}$} & \multirow{2}{*}{$\begin{array}{l}\% \text { age Increase } \\
\text { in } \mathrm{E}_{\mathrm{C}}\end{array}$} & \multirow{2}{*}{$\begin{array}{l}\text { Secant Modulus at } 40 \% \\
\text { Ultimate Load }\left(\mathrm{E}_{\mathrm{SC}}\right)\left(\mathrm{N} / \mathrm{mm}^{2}\right)\end{array}$} \\
\hline & & Glass & Steel & & & \\
\hline 1 & 0.0 & 0.0 & 0.0 & 12941 & -- & 12768 \\
\hline 2 & 0.50 & 0 & 100 & 26242 & 102.78 & 25300 \\
\hline 3 & 0.50 & 25 & 75 & 21968 & 69.75 & 19463 \\
\hline 4 & 0.50 & 50 & 50 & 19437 & 50.19 & 18558 \\
\hline 5 & 0.50 & 75 & 25 & 14339 & 10.80 & 13701 \\
\hline 6 & 0.50 & 100 & 0 & 13279 & 2.61 & 12992 \\
\hline 7 & 0.75 & 0 & 100 & 33831 & 161.42 & 29485 \\
\hline 8 & 0.75 & 25 & 75 & 32127 & 148.25 & 27133 \\
\hline 9 & 0.75 & 50 & 50 & 30666 & 136.96 & 24987 \\
\hline 10 & 0.75 & 75 & 25 & 25055 & 93.61 & 22835 \\
\hline 11 & 0.75 & 100 & 0 & 21422 & 65.54 & 20644 \\
\hline 12 & 1.00 & 0 & 100 & 50597 & 290.98 & 38981 \\
\hline 13 & 1.00 & 25 & 75 & 42378 & 227.47 & 32384 \\
\hline 14 & 1.00 & 50 & 50 & 36995 & 185.87 & 30548 \\
\hline 15 & 1.00 & 75 & 25 & 26479 & 104.61 & 24775 \\
\hline 16 & 1.00 & 100 & 0 & 22820 & 76.33 & 22611 \\
\hline 17 & 1.50 & 0 & 100 & 74307 & 474.19 & 61542 \\
\hline 18 & 1.50 & 25 & 75 & 55685 & 330.29 & 53045 \\
\hline 19 & 1.50 & 50 & 50 & 42089 & 225.24 & 34600 \\
\hline 20 & 1.50 & 75 & 25 & 33779 & 161.02 & 28542 \\
\hline 21 & 1.50 & 100 & 0 & 28380 & 119.30 & 27571 \\
\hline
\end{tabular}

Table 7. Modulus of Elasticity and Secant Modulus of MFRC Specimens With $5 \%$ Microsilica

\begin{tabular}{|c|c|c|c|c|c|c|}
\hline \multirow{2}{*}{$\begin{array}{l}\text { S. } \\
\text { No. }\end{array}$} & \multirow{2}{*}{$\begin{array}{l}\text { Total } \\
\text { Fiber }(\%)\end{array}$} & \multicolumn{2}{|c|}{ Mixed Fiber (\%) } & \multirow{2}{*}{$\begin{array}{l}\text { Modulus of Elasticity } \\
\left(\mathrm{E}_{\mathrm{C}}\right)\left(\mathrm{N} / \mathrm{mm}^{2}\right) \\
\text { (Average) }\end{array}$} & \multirow{2}{*}{$\begin{array}{l}\% \text { age Increase in } \\
\mathrm{E}_{\mathrm{C}}\end{array}$} & \multirow{2}{*}{$\begin{array}{l}\text { Secant Modulus at } 40 \% \\
\text { Ultimate Load }\left(\mathrm{E}_{\mathrm{SC}}\right) \\
\left(\mathrm{N} / \mathrm{mm}^{2}\right)\end{array}$} \\
\hline & & Glass & Steel & & & \\
\hline 1 & 0.0 & 0.0 & 0.0 & 13655 & -- & 13516 \\
\hline 2 & 0.50 & 0 & 100 & 30306 & 121.94 & 29114 \\
\hline 3 & 0.50 & 25 & 75 & 24369 & 78.46 & 21347 \\
\hline 4 & 0.50 & 50 & 50 & 22308 & 63.36 & 19880 \\
\hline
\end{tabular}




\begin{tabular}{|l|l|l|l|l|l|l|}
\hline 5 & 0.50 & 75 & 25 & 21975 & 60.93 & 18663 \\
\hline 6 & 0.50 & 100 & 0 & 18345 & 34.34 & 17542 \\
\hline 7 & 0.75 & 0 & 100 & 54933 & 302.29 & 41740 \\
\hline 8 & 0.75 & 25 & 75 & 43581 & 219.15 & 37381 \\
\hline 9 & 0.75 & 50 & 50 & 39573 & 189.81 & 32496 \\
\hline 10 & 0.75 & 75 & 25 & 33759 & 147.23 & 26280 \\
\hline 11 & 0.75 & 100 & 0 & 29181 & 113.70 & 23712 \\
\hline 12 & 1.00 & 0 & 100 & 70267 & 414.59 & 58000 \\
\hline 13 & 1.00 & 25 & 75 & 61736 & 352.11 & 47444 \\
\hline 14 & 1.00 & 50 & 50 & 49076 & 259.39 & 38090 \\
\hline 15 & 1.00 & 75 & 25 & 41534 & 204.16 & 33650 \\
\hline 16 & 1.00 & 100 & 0 & 36773 & 169.30 & 31248 \\
\hline 17 & 1.50 & 0 & 100 & 93480 & 584.58 & 87960 \\
\hline 18 & 1.50 & 25 & 75 & 78727 & 476.54 & 72133 \\
\hline 19 & 1.50 & 50 & 50 & 72072 & 427.81 & 60314 \\
\hline 20 & 1.50 & 75 & 25 & 53733 & 293.50 & 51025 \\
\hline 21 & 1.50 & 100 & 0 & 41502 & 203.93 & 41410 \\
\hline
\end{tabular}

Table 8. Modulus of Elasticity and Secant Modulus of MFRC Specimens With $15 \%$ Microsilica

\begin{tabular}{|c|c|c|c|c|c|c|}
\hline \multirow{2}{*}{$\begin{array}{l}\text { S. } \\
\text { No. }\end{array}$} & \multirow{2}{*}{$\begin{array}{l}\text { Total } \\
\text { Fiber }(\%)\end{array}$} & \multicolumn{2}{|c|}{ Mixed Fiber (\%) } & \multirow{2}{*}{$\begin{array}{l}\text { Modulus of Elasticity } \\
\left(\mathrm{E}_{\mathrm{C}}\right)\left(\mathrm{N} / \mathrm{mm}^{2}\right) \\
(\text { Average })\end{array}$} & \multirow{2}{*}{$\begin{array}{l}\% \text { age Increase in } \\
\mathrm{E}_{\mathrm{C}}\end{array}$} & \multirow{2}{*}{ 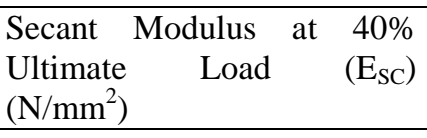 } \\
\hline & & Glass & Steel & & & \\
\hline 1 & 0.0 & 0.0 & 0.0 & 17258 & -- & 15813 \\
\hline 2 & 0.50 & 0 & 100 & 46015 & 166.63 & 40895 \\
\hline 3 & 0.50 & 25 & 75 & 38122 & 120.89 & 35167 \\
\hline 4 & 0.50 & 50 & 50 & 33636 & 94.90 & 33184 \\
\hline 5 & 0.50 & 75 & 25 & 29291 & 69.72 & 28157 \\
\hline 6 & 0.50 & 100 & 0 & 27706 & 60.54 & 26640 \\
\hline 7 & 0.75 & 0 & 100 & 88659 & 413.72 & 87520 \\
\hline 8 & 0.75 & 25 & 75 & 69480 & 302.59 & 47422 \\
\hline 9 & 0.75 & 50 & 50 & 50011 & 189.78 & 35066 \\
\hline 10 & 0.75 & 75 & 25 & 45785 & 165.29 & 32736 \\
\hline
\end{tabular}




\begin{tabular}{|l|l|l|l|l|l|l|}
\hline 11 & 0.75 & 100 & 0 & 39479 & 128.75 & 28171 \\
\hline 12 & 1.00 & 0 & 100 & 103913 & 502.11 & 90400 \\
\hline 13 & 1.00 & 25 & 75 & 83969 & 386.55 & 80400 \\
\hline 14 & 1.00 & 50 & 50 & 76130 & 341.12 & 72566 \\
\hline 15 & 1.00 & 75 & 25 & 63602 & 268.53 & 60628 \\
\hline 16 & 1.00 & 100 & 0 & 46645 & 170.28 & 50700 \\
\hline 17 & 1.50 & 0 & 100 & 121957 & 606.67 & 114600 \\
\hline 18 & 1.50 & 25 & 75 & 97371 & 464.21 & 89760 \\
\hline 19 & 1.50 & 50 & 50 & 87800 & 408.75 & 79818 \\
\hline 20 & 1.50 & 75 & 25 & 75453 & 337.21 & 71233 \\
\hline 21 & 1.50 & 100 & 0 & 66809 & 287.12 & 55147 \\
\hline
\end{tabular}

Table 9. Modulus of Elasticity and Secant Modulus of MFRC with Various Percentages of Microsilica over the Base Reference

\begin{tabular}{|c|c|c|c|c|c|c|c|c|c|}
\hline \multirow{2}{*}{$\begin{array}{l}\text { S. } \\
\text { No. }\end{array}$} & \multirow{2}{*}{$\begin{array}{l}\text { Total } \\
\text { Fiber } \\
(\%)\end{array}$} & \multicolumn{2}{|c|}{$\begin{array}{l}\text { Mixed Fiber } \\
(\%)\end{array}$} & \multicolumn{3}{|c|}{$\begin{array}{l}\text { Percent Increase in Modulus } \\
\text { of Elasticity Over the Base Reference }\end{array}$} & \multicolumn{3}{|c|}{$\begin{array}{l}\text { Percent Increase in Secant Modulus at } \\
40 \% \text { Ultimate Load Over the Base } \\
\text { Reference }\end{array}$} \\
\hline & & Glass & Steel & $0 \%$ & $5 \%$ & $15 \%$ & $0 \%$ & $5 \%$ & $15 \%$ \\
\hline 1 & 0.0 & 0.0 & 0.0 & -- & 5.52 & 33.36 & -- & 5.86 & 23.84 \\
\hline 2 & 0.50 & 0 & 100 & 102.78 & 134.19 & 255.58 & 98.15 & 128.02 & 220.25 \\
\hline 3 & 0.50 & 25 & 75 & 69.75 & 88.31 & 194.58 & 52.43 & 67.19 & 175.43 \\
\hline 4 & 0.50 & 50 & 50 & 50.19 & 72.38 & 159.92 & 45.34 & 55.70 & 159.89 \\
\hline 5 & 0.50 & 75 & 25 & 10.80 & 69.81 & 126.34 & 7.31 & 46.17 & 120.53 \\
\hline 6 & 0.50 & 100 & 0 & 2.61 & 41.76 & 114.09 & 1.75 & 37.39 & 108.65 \\
\hline 7 & 0.75 & 0 & 100 & 161.42 & 324.49 & 585.10 & 130.92 & 226.91 & 585.46 \\
\hline 8 & 0.75 & 25 & 75 & 148.25 & 236.78 & 436.89 & 112.51 & 192.77 & 271.41 \\
\hline 9 & 0.75 & 50 & 50 & 136.96 & 205.79 & 286.45 & 95.70 & 154.51 & 174.64 \\
\hline 10 & 0.75 & 75 & 25 & 93.61 & 160.87 & 253.69 & 78.84 & 105.82 & 156.39 \\
\hline 11 & 0.75 & 100 & 0 & 65.54 & 125.49 & 205.07 & 61.68 & 85.71 & 120.64 \\
\hline 12 & 1.00 & 0 & 100 & 290.98 & 442.98 & 702.97 & 205.30 & 354.26 & 608.02 \\
\hline 13 & 1.00 & 25 & 75 & 227.47 & 377.05 & 548.86 & 153.63 & 274.58 & 529.69 \\
\hline 14 & 1.00 & 50 & 50 & 185.87 & 279.23 & 488.28 & 139.25 & 198.32 & 468.34 \\
\hline 15 & 1.00 & 75 & 25 & 104.61 & 220.95 & 391.15 & 94.04 & 163.55 & 374.84 \\
\hline
\end{tabular}




\begin{tabular}{|l|l|l|l|l|l|l|l|l|l|}
\hline 16 & 1.00 & 100 & 0 & 76.33 & 184.16 & 260.04 & 77.09 & 144.74 & 297.09 \\
\hline 17 & 1.50 & 0 & 100 & 474.19 & 622.36 & 842.41 & 382.00 & 588.91 & 797.56 \\
\hline 18 & 1.50 & 25 & 75 & 330.29 & 508.35 & 683.95 & 315.45 & 464.95 & 603.01 \\
\hline 19 & 1.50 & 50 & 50 & 225.24 & 456.92 & 578.46 & 170.98 & 372.38 & 525.14 \\
\hline 20 & 1.50 & 75 & 25 & 161.02 & 315.22 & 483.05 & 123.54 & 299.63 & 457.90 \\
\hline 21 & 1.50 & 100 & 0 & 119.30 & 220.79 & 416.26 & 115.94 & 224.33 & 331.92 \\
\hline
\end{tabular}

Base Reference: Specimens with no fiber and no microsilica

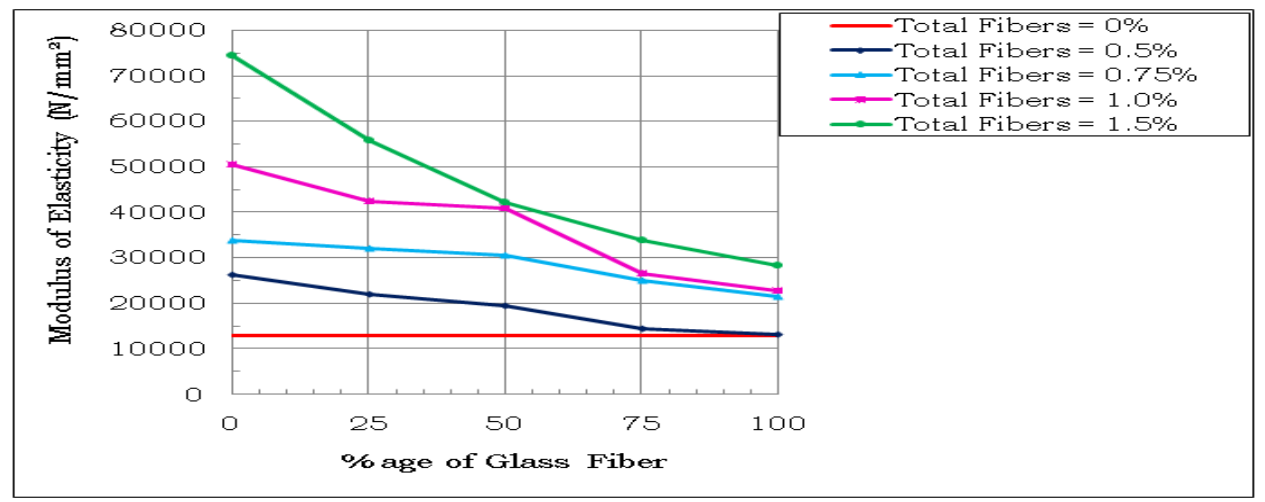

Figure 1. Variation of Modulus of Elasticity of MFRC Cylinders with $0 \%$ Microsilica

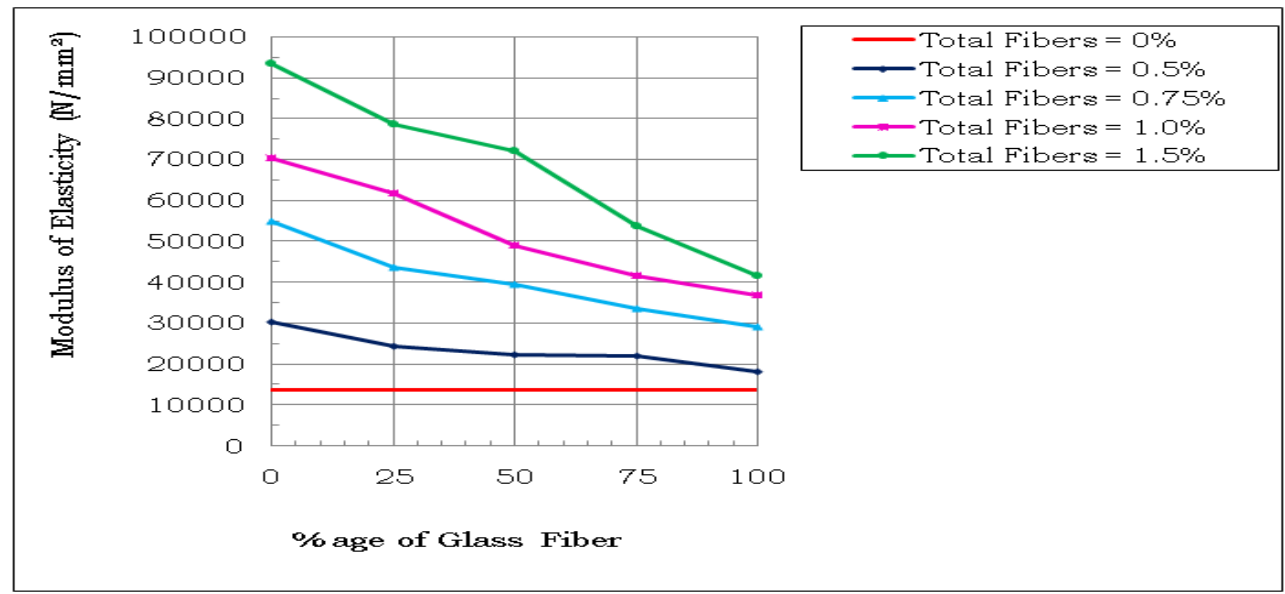

Figure 2. Variation of Modulus of Elasticity of MFRC Cylinders with $5 \%$ Microsilica

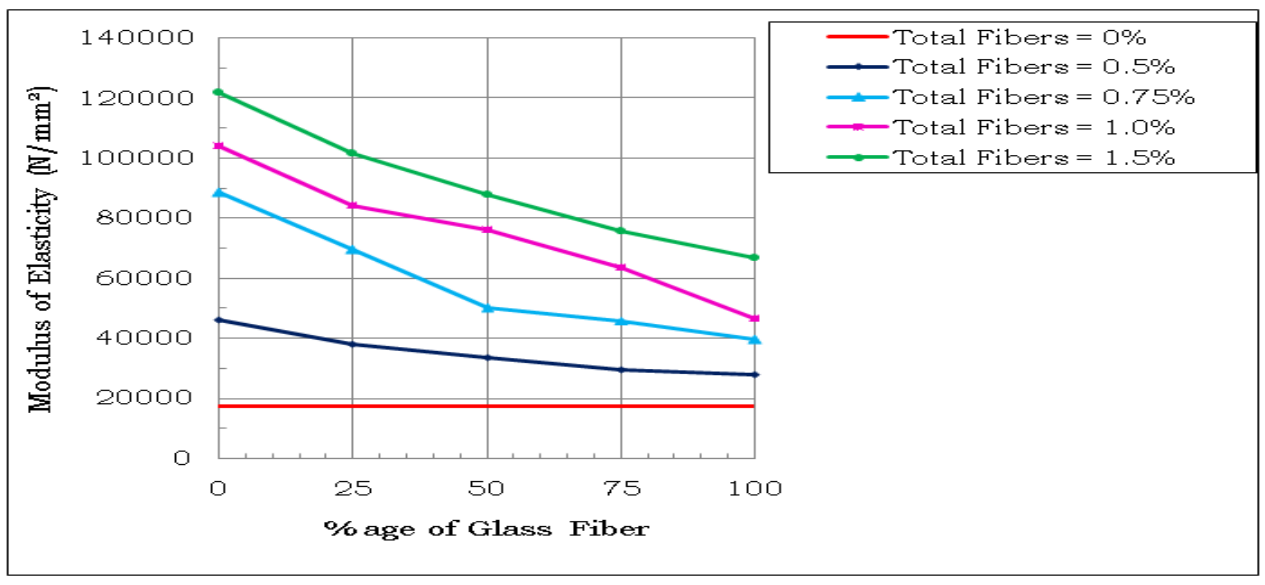

Figure 3. Variation of Modulus of Elasticity of MFRC Cylinders with $15 \%$ Microsilica 